\section{Swimming Baths and Pools}

THE Minister of Health has directed the attention of local authorities for the necessity of cleanliness in swimming pools (Circular 1503. London: H.M. Stationery Office, price ld.). The circular emphasises the opportunity which the winter months offer for ensuring a proper standard in swimming baths and pools. The requisite degree of purity can best be maintained by efficient continuous filtration and continuous controlled chlorination. The recommenda. tions apply to all baths and pools open to the public, whether publicly or privately owned, for local authorities, under the Public Health Act, 1875, have power of control over privately owned pools used by the public.

\section{Pathology and Bacteriology at Leeds}

THE annual report for 1934 of the Department of Pathology and Bacteriology in the University of Leeds has been issued, and gives a brief account of the routine and research work prosecuted under the direction of Profs. Stewart and McLeod. The research work includes studies on industrial pulmonary diseases, diphtheria, immunity, and catarrhs of the respiratory tract. Prof. Passey contributes an abstract of work done in cancer research.

\section{Harrison Memorial Prize, 1935: Dr. L. E. Sutton}

Aт the meeting of the Harrison Memorial Prize Selection Committee, consisting of the presidents of the Chemical Society, the Institute of Chemistry, the Society of Chemical Industry, and the Pharmaceutical Society, held on December 12, it was unanimously decided that the Harrison Memorial Prize for 1935 should be awarded to Dr. Leslie Ernest Sutton. The presentation of the Prize will be made at the annual general meeting of the Chemical Society to be held at the University of Bristol on Thursday, April 16, 1936. Dr. Leslie E. Sutton was educated at Watford Grammar School, and proceeded to Lincoln College, Oxford, in 1925, obtaining his B.A. and B.Sc. with firstclass honours in 1929. He was elected senior research scholar of the Department of Scientific and Industrial Research in 1929, and obtained his D.Phil. and fellowship of Magdalen College in 1932. He worked with Prof. P. Debye at Leipzig and with Prof. L. Pauling at the California Institute of Technology, Pasadena, and during the past five years he has been carrying out research at Oxford. His original investigations on dipole moments, including the relation between moments and orientation in benzene substitution, on valency angles, and on electron diffraction are of outstanding merit, and form a notable contribution to our knowledge of physical chemistry.

\section{"Everyday Science" and the Civil Service Commissioners}

Oun leading article this week deplores the removal from examinations for higher administrative posts of the Civil Service of the compulsory subject "Everyday Science". In this connexion, Sir Arnold Wilson put a question in the House of Commons asking the Secretary to the Treasury "whether he is aware that the Civil Service Commissioners have eliminated the subject of everyday science, which has been one of the obligatory subjects for competitive examinations for the administrative group of Government service, from next year's examinations ; and whether, before taking this decision, the Civil Service Commissioners consulted any society or body representing educational and scientific interests". The reply given on December 16 by the Financial Secretary to the Treasury was as follows : "The answer to both parts of the question is in the negative." The curtness of the reply borders almost on discourtesy to the scientific and educational bodies concerned; and we trust that the matter will not be left in the present unsatisfactory position.

\section{Scales of Ordnance Survey Maps}

IN reply to a question by Colonel A. W. Goodman in the House of Commons on December 12, the Right Hon. Walter E. Elliot, Minister of Agriculture, stated that "no decision has been taken to introduce the metre as a unit of measurement in Ordnance Survey maps. The question is among those to be examined by the Departmental Committee, which is at present considering the future programme of the Ordnance Survey Department."

\section{Committee against Malnutrition}

IN the anniversary address to the Royal Society (Nature, Dec. 7, p. 895), Sir F. Gowland Hopkins mentioned a "self-constituted committee" issuing "propaganda against malnutrition". This Committee -a body of research workers and members of the medical profession-is the Committee against Malnutrition, 19c Eagle Street, Holborn, W.C.1. The Committee issues a two-monthly bulletin dealing with all aspects of modern nutritional research and of malnutrition as a social question. The annual subscription is $3 s$., and in the case of associates $5 s$., a sum which entitles them to the full use of the files and library of the Committee.

\section{Fifth Mount Everest Expedition}

Ir is announced that the party which will make the fifth attempt to climb Mount Everest in the 1935-36 expedition under the leadership of $\mathrm{Mr}$. Hugh Ruttledge has been chosen by the Mount Everest Committee, of which Major-General Sir Percy Cox is chairman. The members of the party will be Mr. E. E. Shipton, leader of the Mount Everest reconnaissance party in Tibet; Mr. F. S. Smythe, who has taken part in three previous expeditions; Mr. P. Wyn Harris (Kenya Civil Service) ; Dr. C. B. Warren, formerly of St. Bartholomew's Hospital ; Mr. E. G. H. Kempson, a master at Marlborough College; Major C. J. Morris, late 2nd/3rd Gurkha Rifles; Dr. Noel Humphreys, who led the Oxford University Expedition to Ellesmere Land last year; Lieut. W. R. Smijth-Windham, Royal Corps of Signals; Lieut. J. M. L. Gavin, Royal Engineers; Mr. F. H. L. Wigram, a medical student at St. Thomas's Hospital ; and Lieut. P. R. Oliver, South Waziristan Scouts. 